(C) 1984 ISIJ

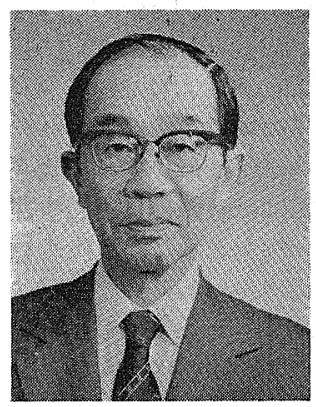

溶鋼のガス吸収に関する二，三の展望

\section{Some Aspects on the Gas Absorption of Liquid Steel}

特別講演

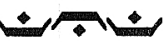

雄*

\section{1. 溶鉄の窒素吸収・脱窒の動力学}

純酸素転炉製鋼法が製鋼の主流となつてきた 1960 年 ごろから，真空脱ガス法の導入とあいまつて，溶鋼・ガ ス間反応の重要性が，あらためて注目されるよらになつ たといえる、殊に，本製鋼法の特徴を生かして低窒素鋼 の開発が要望され，基礎研究の面でも，溶鉄の窒素吸 収，および脱窒に関する速度論的研究が活発に行われは

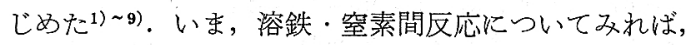
最も注目すべきことは，第一に窒素の移行に対する表面 活性成分である溶鉄内の溶解酸素，あるい生硫黄の影響 であり，第二に一般に窒素吸収反応が一次反応で示され るのに対し，脱窒反応が二次反応で示されるといらよら に，あたか子両反応は反応機構が互いに異なるかのよ5 な結果が得られていることである10). 正逆反応で反応次 数が異なるという例は, 佐野・森ら"1)によつて溶融銀一 酸素系について子認められている. 彼らも指摘している ように，ガス・メタル間反応の一般論として考えると き，反応機構そのものが，正逆で全く異なるとは考え難 く, 溶鉄・窒素系反応子, 気・液界面に打的る反応を含 む混合律速として解勫するのが妥当であるう，最近，

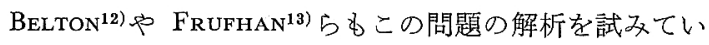
るが，さきに著者らが試みた一連の研究結果を中心に， 要点をまとめてみよう。

\section{$1 \cdot 1$ 窒素吸収速度と界面現象}

溶鉄内溶解酸素，あるいは硫黄が，表面活性元素であ り, 気・液界面に強く吸着されて窒素の移行に大さな抵 抗となることは，多くの研究者によつて認められてお り，今日では周知の事実である。しかし，ここにみられ るよらな表面活性元素による空素の移行に対する界面抵 抗が，これほど著しい例は他にみられない現象である。

いま，酸素あるいは硫黄のきわめて低い溶鉄を考劣る と, 1 気圧窒素のもとでの窒素吸収過程は, 典型的な液 体のガス吸収モデルで表され，その速度は液側の物質移 動律速であり，(1.1)式で表される6).

$$
\frac{d[\% N]}{d t}=\frac{A}{V} \cdot k_{\mathrm{N}}\left(C_{\mathrm{s}}-C\right)
$$

\section{Michio INOUYE}

ここで, $A$ は気・液界面積, $V$ は溶鉄の体積, $k_{\mathrm{N}}$ は窒 素吸収反応の速度常数であるが，この場合は物質移動係 数といらべきものである， $C_{\mathrm{s}} ， C$ はそれぞれ，溶鉄内 $\mathrm{N}$ の飽和濃度, 時間 $t$ に和ける濃度を示す.一般に溶鉄バ ルクは何らかの流動を伴うことが多く，実験室的研究で は主として高周波誘導攪汼のもとで行われているので, このような条件下でのガス吸収は，いわゆる浸透モデ ル，あるいは表面更新モデルで表され， $k_{\mathrm{N}}$ は $\mathrm{N}$ の溶鉄 中の拡散係数 $D_{\mathrm{N}}$ の平方根に比例する. 著者らの実験結 果6)によれば，低酸素領域（0.005〜0.013\% 吕）では， $1600^{\circ} \mathrm{C}$ で $k_{\mathrm{N}}$ の值は, 約 $3.5 \times 10^{-2} \mathrm{~cm} / \mathrm{s}$ である.も らろんこの值は高周波誘導攪汼の強弱によつて变わるも のであるが， Sieverts 法によつて測定した PEHLKE，

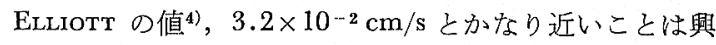
味深い.

さて，この物質移動係数 $k_{\mathrm{N}}$ に及ぼす，溶鉄内溶解酸 素, あるいは硫黄の影響は, 前述のごとくきわめて大き いが，著者らの研究結果 ${ }^{7) 8 な と め る と ~ F i g . ~} 1$ のよう になる、図から明らかなよらに, 酸素も硫黄も, その濃 度が $0.03 \%$ 附近から， $k_{\mathrm{N}}$ の值は急激に低下しはじめ， 酸素はさらに増加して飽和に近つくにつれさらに低下 乙, 酸化皮膜の生成とともに0に近づくるのと考党られ

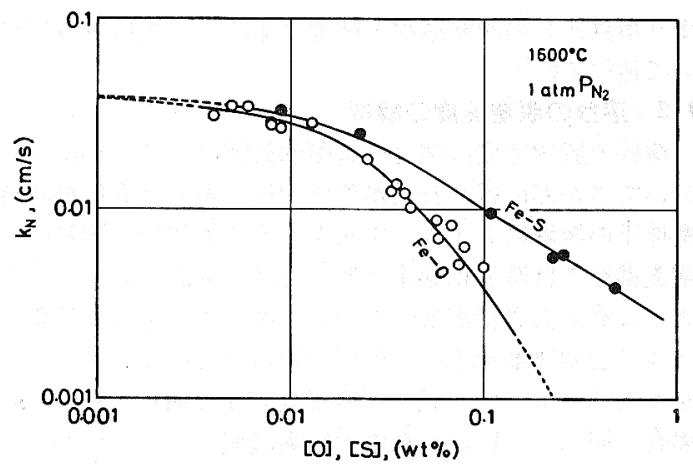

Fig. 1. Effects of oxygen and sulfer on the overall masstransfer coefficient of nitrogen absorption at $1600^{\circ} \mathrm{C}$. data of $\left.\mathrm{CHOH}_{\text {, INOUYE }}{ }^{7)} \sim 9\right)$. 


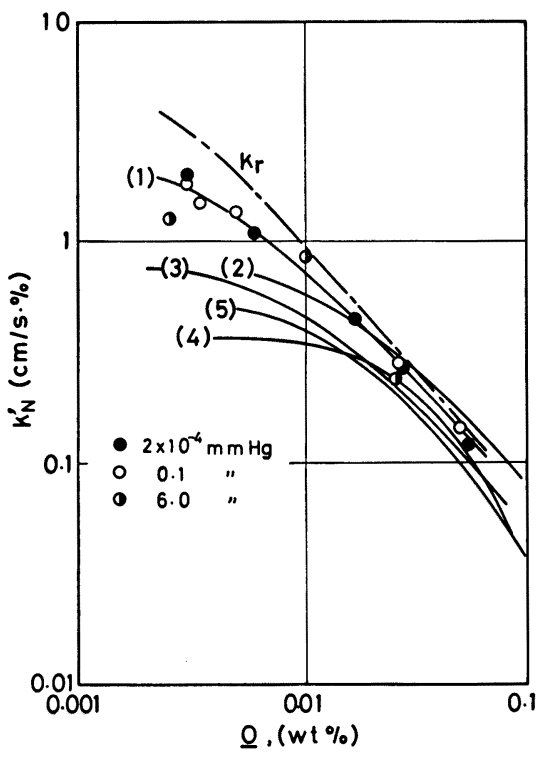

Fig. 2. Effect of oxygen on the overall masstransfer coefficient of nitrogen desorption at $1600^{\circ} \mathrm{C}$.

1) Сhoh, Inouye 2) Ban-ya et al. 3) Suzuki et al. 4) Narita et al. 5) Shinmyo et al. $k_{\mathrm{r}}$ represents the chemical reaction rate constant of nitrogen desorption.

る. 一方, 硫黄の影響は比較的高濃度までほぼ直線的で あるが，さらに高濃度領域までは明らかでない，逆に， 酸素, 硫黄とも0に近づくにつれ， $k_{\mathrm{N}}$ の值は $4.0 \sim 5.0$ $\times 10^{-2} \mathrm{~cm} / \mathrm{s}$ に近づく，つまり，本実験に用いた高周波 誘導攪拌のもとでの, $1600^{\circ} \mathrm{C}$ に打ける純鉄の窒素吸収 の物質移動係数を意味し, この場合, 窒素の吸収は 100 \%液側物質移動律速であることを示すものである. 酸素 が，あるいは硫黄が高くなるにつれ，界面反応と液側物 質移動との混合律速となるが，このことは，逆反応，つ まり溶鉄からの脱窒過程と関連するので, 次に脱窒につ いて述べる.

\section{2 溶鉄の脱窒速度の解析}

溶鉄の脱窒速度に関する基礎的研究は，特にわが国に おいてさかんに行われたが10)14) 17)，多くは高周波誘導 攪拌下の溶鉄にアルゴンを吹きつける方法で，溶鉄中の 窒素濃度の経時変化を求めることにより試みられた. 著 者らは高周波真空溶解炉を用い, 減圧下で種々の酸素レ ベルで脱窒速度を求めた18)19).Fig. 2 はこれらの結果 をまとめたもので, 脱窒速度定数 $k^{\prime}{ }_{\mathrm{N}}$ は明らかに吸収の 場合と同じように，溶鉄中の酸素濃度とともにいちじる しく低下する.この事実は，多くの研究者によつて認め られているが，ここで注目すべきことは，各測定者によ つて高酸素領域では比較的よく一致しているものの，低 酸素領域, つまり純鉄に近づくにつれ不一致が目立つこ とである，実験結果は，いずれの測定者によつても，
(1.2)式であらわされるような二次反応式で整理できる.

$$
-\frac{d[\% \mathrm{~N}]}{d t}=\frac{A}{V} \cdot k_{\mathrm{N}}^{\prime} \cdot[\% \mathrm{~N}]^{2}
$$

この点から考えて, 脱窒速度を界面反応律速として解析 した例が多(10)14)15)が, 著者らは前述のように, 低酸素 領域での測定者間の不一致の原因は, 液側物質移動の寄 与を無視したためであると考光, 次のような混合律速モ デルを適用した，すなわち(1液相バルクから気液界面へ の窒素原子の移行, (2)界面における窒素分子の生成之離 脱, (3)窒素分子の界面から気相バルクへの移行を(1.3), (1.4), (1.5)式で表す.

$$
\begin{aligned}
-\dot{n}_{1} & =A \cdot k_{1}\left(C_{\mathrm{b}}-C_{\mathrm{i}}\right) \\
-\dot{n}_{\mathrm{r}} & =A \cdot k_{\mathrm{r}}\left(C_{1}^{2}-C_{\mathrm{e}}^{2}\right) \cdots \cdots \ldots \ldots \ldots \ldots \\
-\dot{n}_{\mathrm{g}} & =A \cdot k_{\mathrm{g}}\left(p_{\mathrm{N}_{2} \mathrm{i}}-p_{\mathrm{N}_{2} \mathrm{~b}}\right) / R T \\
& =A \cdot k_{\mathrm{g}}^{\prime}\left(p_{\mathrm{N}_{2} \mathrm{i}}-p_{\mathrm{N}_{2} \mathrm{~b}}\right) \cdots \cdots \cdots
\end{aligned}
$$

ここで， $\dot{n}_{1}, \dot{n}_{\mathrm{r}}, \dot{n}_{\mathrm{g}}$ はそれぞれ，液相内移行速度，界面 反応速度, 気相内移行速度を $\mathrm{mol} / \mathrm{s}$ であらわし, また $k_{1}$ は液相内物質移動係数 $(\mathrm{cm} / \mathrm{s}), k_{\mathrm{r}}$ は界面反応速度定 数 $\left(\mathrm{cm}^{4} / \mathrm{mol} \cdot \mathrm{s}\right), k_{\mathrm{g}}$ は気相内物質移動係数 $(\mathrm{cm} / \mathrm{s})$ をあ らわす. バルク濃度 $C_{\mathrm{b}}$, 界面濃度 $C_{\mathrm{i}}$ は $\mathrm{mol} / \mathrm{cm}^{3}$ で, また気相分圧 $p_{\mathrm{N}_{2} \mathrm{~b}}$ は atm 単位であらわす. 総括反応 速度 $\dot{n}_{\mathrm{OV}}$ は(1.6)式であらわす.

$$
-\dot{n}_{\mathrm{ov}}=A \cdot k_{\mathrm{ov}}\left(C_{\mathrm{b}}^{2}-C_{\mathrm{e}}^{2}\right)
$$

いま定常状態， $\dot{n}_{1}=\dot{n}_{\mathrm{r}}=2 \dot{n}_{\mathrm{g}}=\dot{n}_{\mathrm{OV}}$ を考えると，(1.7) 式 の関係式が得られる. $p_{\mathrm{N}_{2} \mathrm{~b}}=0$ とすると

$$
k_{\mathrm{OV}}=k_{\mathrm{l}}\left(\frac{2 C_{\mathrm{b}}+\phi-\sqrt{\phi^{2}+4 \phi C_{\mathrm{b}}}}{2 C_{\mathrm{b}}^{2}}\right)
$$

ただし， $\phi=k_{1} / k_{\mathrm{r}}$ とする.このように取り扱らと，脱 窒速度は (1.8)式であらわすことができる.

$$
-\frac{d[\% \mathrm{~N}]}{d t}=\frac{A}{2 V} \cdot k_{1}\left(2 C_{\mathrm{b}}+\phi-\sqrt{\phi^{2}+4 \phi C_{\mathrm{b}}}\right)
$$

いま，窒素吸収に関する前述の結果から，酸素を含まな い純鉄の物質移動係数 $k_{\mathrm{N}}$ を $5.0 \times 10^{-2} \mathrm{~cm} / \mathrm{s}$ と見積も つたが，この值は本実験に用いた高周波真空溶解炉の条 件（周波数 $f=3 \mathrm{kHz}$ ） に補正すると， $k_{1}=6.3 \times 10^{-2}$ $\mathrm{cm} / \mathrm{s}$ になる.ここで, 溶鉄のバルク濃度 : $C_{\mathrm{b}}=0.01 \%$

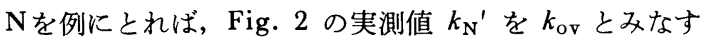
と, (1.7)式から申が求まり, さらに $k_{\mathrm{r}}$, 寸なわち物質 移動抵抗を含まない純化学反応速度定数が得られる.

Fig. 2 の鎖線はこのよらにして求めた $k_{\mathrm{r}}$ と溶鉄内酸 素濃度の関係を示すむのである.すなわち，この值は低 酸素領域までほぼ酸素濃度に逆比例していることが明ら かである. 従来の測定者による $k_{\mathrm{N}}{ }^{\prime}$ の值が低酸素領域で かなり相違していることは, 酸素濃度が低くなるほど溶 鉄内物質移動抵抗の割合が大きくなることによるるの で, 個々の測定条件, 特に溶鉄の流動速度の違いを考虑 すれば理解できる.すなわち，ここで示した $k_{\mathrm{r}}$ の值を もとに， $k_{1}$ をパラメータとして $\phi$ の值をきめ，さらに 
(1.7)式から任意の条件下の $k_{\mathrm{ov}}$ を算出することができ る.

\section{3 鉄-クロム合金の窒素吸収と脱窒}

クロムは溶鉄の窒素溶解度をいちじるしく増大するこ とはよく知られているが, 窒素吸収の速度定数にはほと んど影響を及ぼさない. Fig. 3 は, Sieverts 法によつて 測定した二, 三の鉄ークロム合金についての速度定数 $k_{\mathrm{N}}$ と酸素濃度との関係 ${ }^{20)}$ を示したもので, 本質的にはク口 ムを含まない溶鉄のそれとほとんど差異は認められな い.しかしながら，ステンレス鋼のような高クロム鋼の 脱窒による窒素含量の 低下は困難であるといわれてい る. 事実上，著者らの高周波真空溶解炉を用いた，鉄ーク ロム合金の脱窒実験においても, クロム濃度が高いほど 脱窒しにくく, Fig. 4 は $1600^{\circ} \mathrm{C}, 10^{-2} \sim 10^{-3} \mathrm{mmHg}$

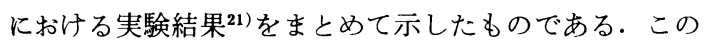
結果は, さきに述べたように, 窒素吸収に比し, 脱窒反 応は界面反応の寄与が大きいため, クロムによる窒素の

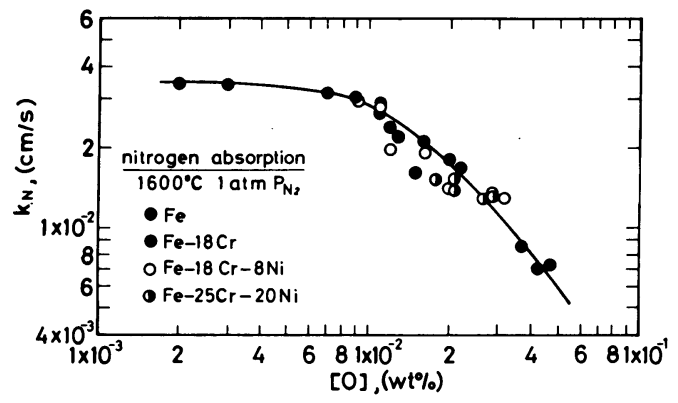

Fig. 3. Effect of oxygen on the overall masstransfer coefficient of nitrogen absorption in liquid ironchromium alloys. Снон, Yamada, INOUYE ${ }^{20)}$.

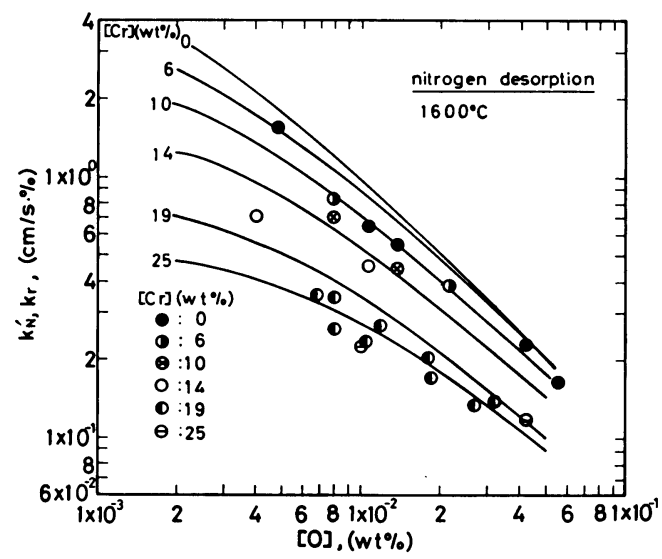

Fig. 4. Effect of oxygen on the overall masstransfer coefficient of nitrogen desorption of liquid ironchromium alloys. data of $\mathrm{CHOH}_{\mathrm{H}}$, TAKEBE, INOUYE ${ }^{21)}$. Solid lines represent the chemical reaction rate constant calculated by Eq. 1. 14 .
活量の低下が直接脱空速度に影響を及ぼすものと解积す ることができる，脱窒反応を支配する界面反応そのもの の機構については，必ずしも明らかにされているとはい い難く, 鉄-クロム系を対象とする本実験結果は, これ までに報告された関係式15) を満足しない，いま界面で は (1.9) 式で示される吸着平衡が成り立ち, 窒素は吸着 site， $\theta_{\mathrm{N}}$ を通して移行すると考学る.

$$
\theta_{\mathrm{N}}=K_{\mathrm{N}} a_{\mathrm{N}} /\left(1+K_{\mathrm{O}} a_{\mathrm{O}}+K_{\mathrm{N}} a_{\mathrm{N}}\right)
$$

ここで, $a_{\mathrm{N}}$ 㧊よび $a_{\mathrm{O}}$ は窒素打よび酸素の活量, $K_{\mathrm{N}}$ 打 よび $K_{\mathrm{O}}$ はそれぞれの吸着平衡定数である。このとき， 界面を窒素が移行する速度は, 未吸着 $\mathrm{N}$ の界面での移動 律速で $\mathrm{N}_{2}$ 分子の生成, 離脱は速いと考光ると, 窒素の 移行速度は, (1.10)式の上らに有効界面積 $\theta_{\mathrm{N}}$ および界 面濃度 $C_{i}$ の関数で表される.

$$
-\dot{n}_{\mathrm{r}}=K_{\mathrm{r}}^{\prime} \theta_{\mathrm{N}} C_{\mathrm{i}}
$$

ここで $C_{\mathrm{i}}$ は物質移動過程を考光るので濃度で表すこと ができ，また酸素は窒素よりも強く吸着するとみれば, $K_{\mathrm{O}} a_{\mathrm{O}} \gg K_{\mathrm{N}} a_{\mathrm{N}}$ とみなすことができる。 それゆえ，脱窒 速度は結局 (1.11) 式のようになる。

$$
\begin{aligned}
& \quad-\dot{n}_{\mathrm{r}}=\left[k_{\mathrm{r}}{ }^{\prime} K_{\mathrm{N}} f_{\mathrm{N}} /\left(1+K_{\mathrm{O}} a_{\mathrm{O}}\right)\right] C_{1}^{2} \\
& \text { ここで } \\
& k_{\mathrm{r}}=k_{\mathrm{r}}{ }^{\prime} K_{\mathrm{N}} f_{\mathrm{N}} /\left(1+K_{\mathrm{O}} a_{\mathrm{O}}\right)
\end{aligned}
$$

と拈けば，(1.4)式と同じ形となり，脱窒速度は見掛け 上 2 次式で表される。また， $\mathrm{Fe}-\mathrm{O}$ 系溶鉄の脱窒速度の 測定結果を用いると(1.12)式は(1.13) 式のようになる.

$$
k_{\mathrm{r}}=10 f_{\mathrm{N}} /\left(1+953 a_{\mathrm{O}}\right)
$$

Fig. 4 の実線は $C_{\mathrm{b}}=0.01 \% \mathrm{~N}$ の条件下で(1.13) 式か ら計算した $k_{\mathrm{r}}$ を示するので液相内の物質移動抵抗が無 視できる条件のもとで達せられる脱窒速度の限界を意味 する21).

\section{4 窒素吸収・脱窒についてのまとめ}

以上述べてきたように，溶鉄の窒素吸収ならびに脱窒 に関する基礎的研究から, 気・液界面を通しての窒素の 移行に, 溶鉄中の酸素, あるいは硫黄の影響がいちじる しいことが明らかである. 従つて一般の溶鋼では, 大な り小なり, 窒素の吸収にも脱窒にも, 一種の界面抵抗が 存在すると考兄なければならないささきに 1.2 で試み た混合律速モデルによる脱窒反応の解析手法を，あらた めて窒素吸収に適用寸ると, 気相内物質移動抵抗を無視 すれば，このときの総括物質移動係数は(1.14)式で表さ れる.

$$
k_{\mathrm{ov}}=k_{1}\left\{\frac{\sqrt{4 C_{\mathrm{b}} \phi+\phi^{2}+4 C_{\mathrm{e}}^{2}}-\left(2 C_{\mathrm{b}}+\phi\right)}{2\left(C_{\mathrm{e}}-C_{\mathrm{b}}\right)}\right\}
$$

ここで $\phi$ は前述のとおり $k_{1} / k_{\mathrm{r}}$ を意味する. いま $k_{1}=$ $5.0 \times 10^{-2} \mathrm{~cm} / \mathrm{s}$ をとり, $C_{\mathrm{e}}=0.0448 \% \mathrm{~N}, C_{\mathrm{b}}=0.01 \% \mathrm{~N}$ とすると，(1.14)式から $k_{\mathrm{ov}}$ に実測值を代入して， $k_{\mathrm{r}}$ と 酸素濃度の関係を求めることができる. Fig. 5 は, こ のようにして求めた窒素吸収のときの界面反応速度定数 


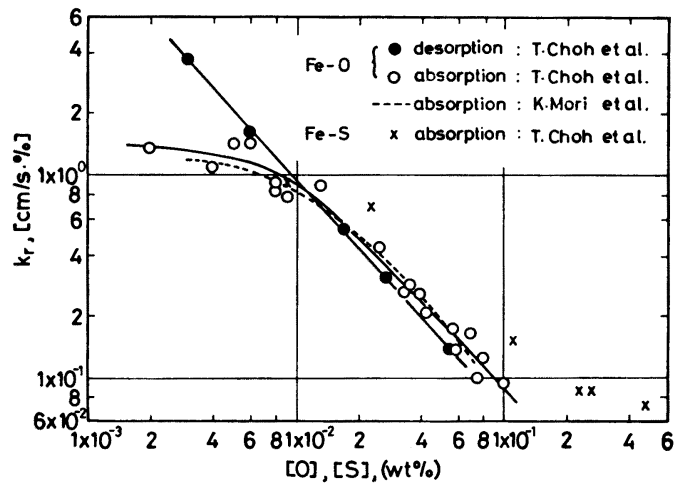

Fig. 5. Effects of oxygen and sulfer on the chemical reaction rate constant of nitrogen absorption and desorption.

を図示したものであるが，興味あることは，最近，森・

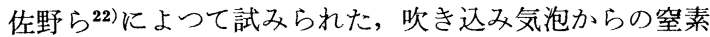
吸収速度に関する事験結果から求められた值ときわめて よい一致を示すことである.また一方，Fig. 5 には， さきに示した脱窒のさいの $k_{\mathrm{r}}$ と酸素濃度との関係も図 示してあるが，これともお执むねよく一致しており，気一 液界面を通して移行する窒素の界面反応は, 正, 逆とも ほとんど同じ速度定数で表されることは興味深い。

ここで, 気相内物質移動抵抗を無視し, 液相内物質移 動抵抗および界面反応抵抗の割合を，それぞれ $r_{1}$, およ び $r_{i}$ として, 吸収ならびに脱窒の場合を比較すると,

Fig. 6 および Fig. 7 のようになる.この場合, 一応 バルク N濃度を $0.01 \%$ とした。図には，液相内流動の 強さに応じ， $k_{1}$ をパラメータとして，それぞれの抵抗 が，溶鉄内酸素濃度に応じて変化することを示してい る、図から明らかなよらに, 吸収の場合は脱窒に比べる 之, 全体として界面反応抵抗の割合が小さいが，高酸素 領域で, 強い攪汼のもとでは, 界面反応抵抗の割合がき わめて大きい，反対に，脱窒の場合は全体として界面反 応抵抗が大きい。

\section{5 高温度における窒素吸収と界面現象}

一般に溶液が表面活性成分を含むとき，その表面張力 は温度上昇とともにかえつて大きくなることが知られて いる ${ }^{23)}$. 溶鉄-酸素系についてもこのことは十分考えら れる、そこで高温度領域における窒素吸収速度に及ぼす 溶鉄内酸素の影響を調べてみよう.

いま, 窒素吸収の物質移動係数と温度との関係は, (1.15)式であらわされるものと考える。

$$
k_{\mathrm{N}}=C_{1} \exp \left(-\frac{E+\Pi \Delta A}{k T}\right)
$$

ここで, $\Delta A:$ 気液界面で $\mathrm{N}$ 原子の占めるサイト, $k:$ Boltzmann const., $C_{1}$ : 常数, $\Pi$ : 表面圧 $\left(\sigma-\sigma_{0}\right), E$ : 純鉄の窒素吸収の活性化エネルギー, $T$ : 絶対温度であ る. (1.15)式から, 表面圧 $I$ とて Kozakevitch らの

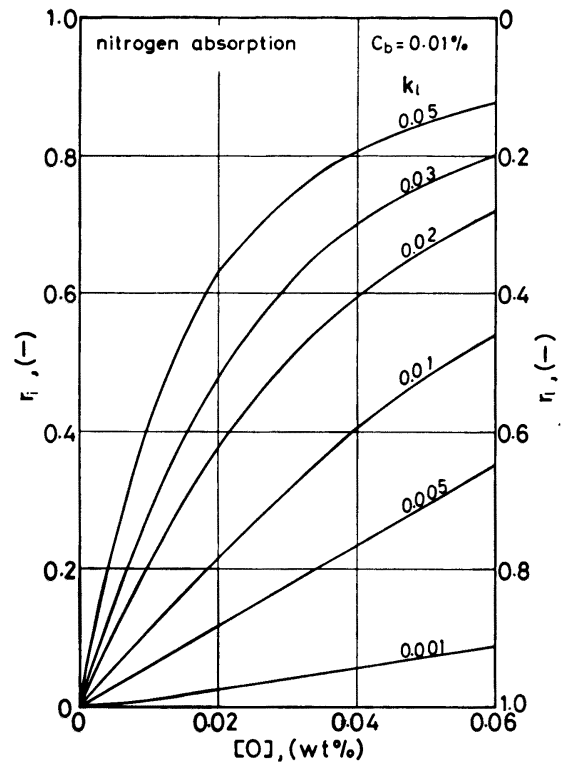

Fig. 6. Estimation of the ratio of masstransfer in liquid iron and chemical reaction at gas-metal interface. (nitrogen absorption)

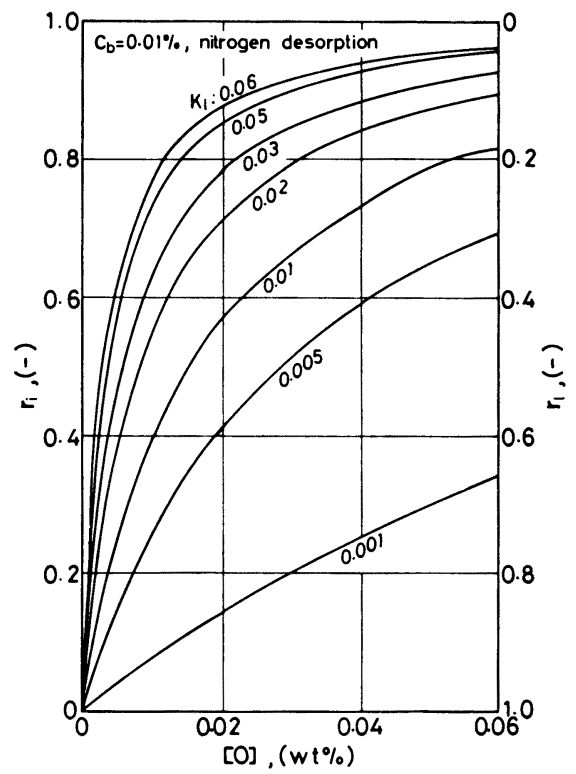

Fig. 7. Estimation of the ratio of masstransfer in liquid iron and chemical reaction at gas-metal interface. (nitrogen desorption)

$\mathrm{Fe}-\mathrm{O}$ 系溶鉄の表面張力の測定値 ${ }^{24)} と り ，$ 著者らの $k_{\mathrm{N}}$ の実験值から $\Pi \Delta A$ の值が求められる. $\Pi \Delta A$ の物理的 意味は, 表面活性成分の窒素の移行に対する界面抵抗の 大ささを示すものとみなすことができる．いま，測定温 


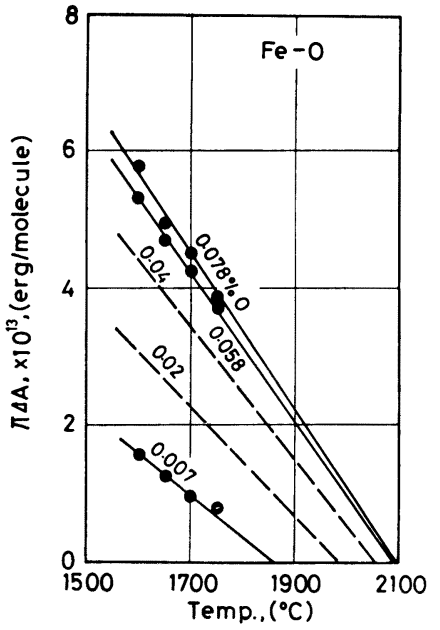

Fig. 8. Temperature dependence of $\Pi \Delta A$ of liquid iron containing oxygen. $\mathrm{CHOH}$, INOUYE ${ }^{25)}$.

度 $T^{\mathbf{\theta}}$ のときの実測值 $k_{\mathrm{N}}^{0}$ およびこのときの界面抵抗を $(\Pi \Delta A)^{0}$ とすると，任意の温度 $T$ における $\Pi \Delta A$ は (1.16)式から求めることができる.

$$
\ln k_{\mathrm{N}}^{0}+\frac{(E+\Pi \Delta A)^{0}}{k T^{0}}-\ln k_{\mathrm{N}}-\frac{E}{k T}=\frac{\Pi \Delta A}{k T}
$$

ここで $1550^{\circ} \sim 1750^{\circ} \mathrm{C}$ における二, 三の酸素レベルで の $k_{\mathrm{N}}$ の実験值を入れて $\Pi \Delta A$ と温度との関係を求める と, それぞれの酸素レベルでよい直線関係が得られ，こ れを基にして任意の酸素レベル，より高温度領域にまで 外插すると Fig. 8 のよらになる25). すなわち, $2000^{\circ} \mathrm{C}$ 以上の高温度になると, 窒素吸収に対する界面抵抗は, 酸素濃度が高くてもほとんど零に近づき，事実上酸素は もはや表面活性ではなくなると考えてよい。このことは 硫黄についても全く同じである。

\section{2. 溶鉄の酸素吸収}

酸化性ガス雾囲気下に括ける溶鉄あるいは溶融鉄合金 の酸化，もしくは酸素吸収を扱つた研究はこれまでも少 なくない。これらを大別すると，気液界面に酸化物が生 成した状態での酸化速度を測定した場合26) 30) と，肉眼 的には酸化皮膜の存在しない条件下での酸素吸収速度を

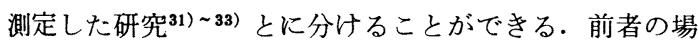
合は, 比較的高濃度の酸化性ガスのもとでの酸化現象を 対象としたものであるが，ここではこの問題にはふれな い. 後者の場合は, 酸化性ガスの分圧がきわめて低い範 用のもので, $\mathrm{H}_{2}-\mathrm{H}_{2} \mathrm{O}-\mathrm{Ar}$ 混合ガス, あるいは $\mathrm{Ar}-\mathrm{O}_{2}$, $\mathrm{N}_{2}-\mathrm{O}_{2}, \mathrm{Ar}-\mathrm{CO}_{2}$ などの混合ガスからの酸素吸収を扱つ たものが報告されている31)32). いずれもこれらのガスか らの酸素吸収は, 気相側の物質移動律速であることを裏 付けている.すなわち, 酸素吸収速度を $\dot{n}_{\mathrm{O}_{2}}(\mathrm{~mol} / \mathrm{s})$ で
あらわすと，それは(2.1)式であらわされる。

$$
\dot{n}_{\mathrm{O}_{2}}=k_{\mathrm{G}} \cdot A \cdot\left(p_{\mathrm{O}_{2}}^{\mathrm{b}}-p_{\mathrm{O}_{2}}^{\mathrm{i}}\right) / R T_{\mathrm{f}}
$$

ここで， $k_{\mathrm{G}}$ は気相内物質移動係数 $(\mathrm{mol} / \mathrm{s}), A$ は界 面積 $\left(\mathrm{cm}^{2}\right), p_{\mathrm{O}_{2}}^{\mathrm{b}}$ および $p_{\mathrm{O}_{2}}^{\mathrm{1}}$ はそれぞれ気相バルクおよ び界面の酸素分圧 $(\mathrm{atm}), R$ はガス定数， $T_{\mathrm{f}}$ は界面に 接するガス温度 $(\mathrm{K})$ である. (2.1) 式は自由落下滴やレ ビテーション溶解溶鉄の酸素吸収に MCLEAN ら ${ }^{33)}$ が適 用できることを確かめている.

酸素吸収についての著者らの実験結果 ${ }^{34)}$ む，(2.1) 式 で整理することができ，吸収速度は一定ガス流速のもと で気相の酸素分圧に比例する.このような条件下でも, 溶鉄表面には，溶鉄バルクの酸素濃度が飽和値に達する 以前から，酸化物皮膜の小片が観察されるが，いま気・ 液界面に到達した酸素は，まず微小な酸化膜をつくり， 残りが溶鉄中に溶解すると考え，(2.2) 式で酸素吸収速 度をあらわした ${ }^{34) 35)}$.

$$
\frac{d[\% \mathrm{O}]}{d t}=\frac{F_{2}}{V} k_{0}\left(\bar{C}_{\mathrm{e}}-C\right)+\frac{F_{1}-F_{2}}{V} k_{1}\left(C_{\mathrm{s}}-C\right)
$$

ここで, $F_{1}, F_{2}$ : 全気液界面積および酸化物の存在しな い気液界面積 $\left(\mathrm{cm}^{2}\right), \bar{C}, C_{\mathrm{s}}$ : 気相との 平均平衡酸素 濃度および飽和酸素濃度（wt $\%$ ）を，また $k_{\mathrm{o}} ， k_{1}$ は酸 化物の存在しない界面を通した酸素移行の総括物質移動 係数および液相内物質移動係数 $(\mathrm{cm} / \mathrm{s})$ である.また $\alpha$ を酸化物の存在する界面積比とし, 二, 三の仮定のもと に(2.2) 式を展開すると，(2.3) 式が得られる. ここで $M_{\mathrm{O}_{2}}$ は酸素分子量, $\rho$ は溶鉄の密度, $k_{\mathrm{r}}$ は界面反応速 度定数 $\left(\mathrm{mol} / \mathrm{s} \cdot \mathrm{cm}^{2} \cdot \mathrm{atm}^{1 / 2}\right)$ をあらわす.

$$
\begin{aligned}
& \frac{d[\% \mathrm{O}]}{d t}=\frac{F_{1}}{V}\left[\frac{100 \cdot M_{\mathrm{O}_{2}}}{\rho} k_{\mathrm{g}} p_{\mathrm{O}_{2}}\left(1-\frac{\alpha}{2}\right)\right. \\
& \left.-\alpha\left\{\frac{100 \cdot M_{\mathrm{O}_{2}}}{\rho} k_{\mathrm{r}}\left(\frac{p_{\mathrm{O}_{2}}}{2}\right)^{1 / 2}-k_{1}\left(C_{\mathrm{s}}-C\right)\right\}\right]
\end{aligned}
$$

(2.3) 式に実験值および既知の物性値を代入して，任 意の条件下における酸素吸収曲線を求めることができ る. 一例として $p_{\mathrm{O}_{2}} ; 0.1 \mathrm{~atm}$ に打ける 純鉄の酸素吸収 速度は Fig. 9 で示され, 同時に (2.3) 式の右辺各項か ら, 時間 $t$ における界面に酸化物として蓄積される酸素 量 $\Delta \mathrm{O}_{\mathrm{ox}}$, 自由表面を通した酸素吸収量 $\mathrm{O}_{\mathrm{f}} お$ よび酸化 物の溶解による酸素吸収量 $\mathrm{O}_{\mathrm{d}}$ を求めることができ, Fig. 9 にその結果を示した. 図から明らかなように，大 部分の酸素吸収は酸化物を経ずに直接自由表面を通して 進さすのとみなすことができる.ク口ムなどの合金元素 を含むときは，当然 $\Delta \mathrm{O}_{\mathrm{ox}}$ の割合が大きくなるが36), やはり大部分の酸素吸収は自由表面を通して進むことに 変わりはない.

\section{3. 液柱流のガス巻き込みとガス吸収}

\section{$3 \cdot 1$ モデル実験によるガス巻き込みの測定}

液体の注入流のガス巻き込み現象は複雑で, これを正 


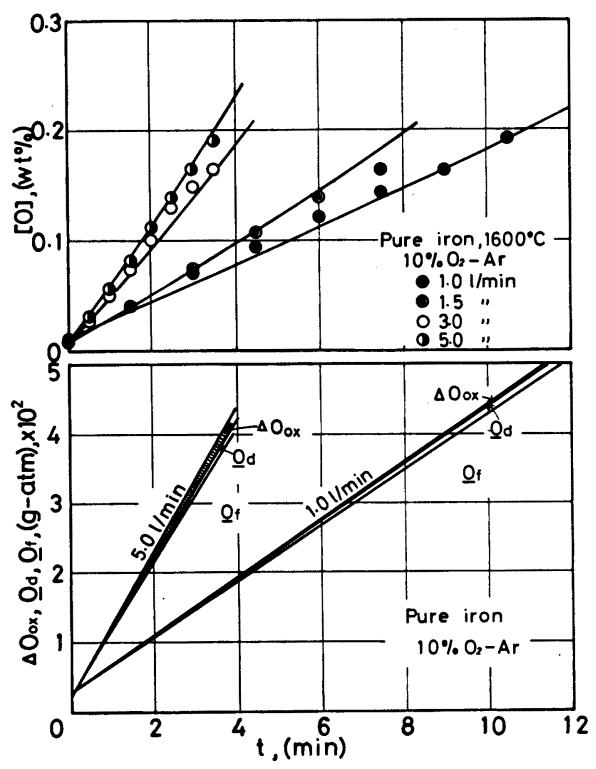

Fig. 9. Rate of oxygen absorption in liquid iron from $\mathrm{Ar}-\mathrm{O}_{2}$ gas mixtures. $\mathrm{CHOH}$, INoUYE ${ }^{34) 35)}$.

確に把握することは非常にむずかしいが，著者らは溶鋼 注入時のガス巻き込みによる溶鋼の酸素ならびに窒素吸 収量を知る目的で，二，三のモデル実験を試みた ${ }^{37) 38) . ~}$ 実験内容の詳細は省略するが，実験結果から，液柱の乱 れ部分の持つ運動エネルギーがガス巻き込みを支配する 要因であるとみなし，これが液面に衝突するとき形成さ れるキャビティの最大半径を求め，(3.1) 式によつてガス 巻き込み速度をあらわすことができることを確かめた.

$$
V_{\mathrm{g}}=0.02 V_{1}\left\{\left(R_{\mathrm{c}}-a\right) / a_{0}\right\}^{3} \text {. }
$$

ここで, $V_{\mathrm{g}}$ : ガス巻き込み速度 $\left(\mathrm{cm}^{3} / \mathrm{s}\right), V_{1}$ : 液 注 入 速度 $\left(\mathrm{cm}^{3} / \mathrm{s}\right), R_{\mathrm{c}}$ : キャビティ半径 $(\mathrm{cm}), a:$ 液柱半 径 $(\mathrm{cm}), a_{0}$ ：ノズル出口での液柱半径 $(\mathrm{cm})$ を示す. キャビティ半径 $R_{\mathrm{c}}$ は, SANDE ら $^{39}$ による溶滴の衝突 から求めた 微分方程式から，(3.2) 式によつて求められ る.

$$
R_{\mathrm{c}}=\left\{\left(1.14+0.00089 E_{1}\right)^{1 / 2}-1.067\right\}^{1 / 2} \cdots \cdots(3.2)
$$

また， $E_{1}$ は液柱乱れ部分の質量 $m$ の衝突時の運動エネ ルギーで，(3.3)，(3.4)式から計算される.

$$
\begin{aligned}
& E_{1}=1 / 2 m u^{2} \ldots \ldots \ldots \ldots \\
& m=\pi \rho \lambda\left(2 a \varepsilon-\varepsilon^{2} / 2\right)
\end{aligned}
$$

ここで, $u$ : 液速度 $(\mathrm{cm} / \mathrm{s}), \rho:$ 液密度 $\left(\mathrm{g} / \mathrm{cm}^{3}\right), \lambda:$ 乱れの波長 $(\mathrm{cm}), \varepsilon:$ 液の乱れ $(\mathrm{cm})$ であり, また液 柱の安定理論から (3.5), (3.6) 式によつて, 距離 $Z$ に おける液柱半径 $a$ が求められる. $u_{0}$ はノズル出口の液 流速を示す.

$$
\begin{aligned}
& a=a_{0} \xi^{-2} \\
& \xi=\left(2 g Z / u_{0}^{2}+1\right)^{1 / 8}
\end{aligned}
$$

また連続の条件を用いると， $Z$ での速度 $u$ は

$$
u=u_{0} \xi^{4}
$$

となる. 液柱の乱れに関する実験結果から, 液柱 乱れ $\varepsilon$, および初期乱れ $\varepsilon_{0}$ は, 実験式 (3.8)，および (3.9) で与えられ，これらを用いると前述の (3.1) 式からガ ス 巻き込み速度 $V_{\mathrm{g}}$ が得られる。

$$
\begin{aligned}
& \varepsilon=\varepsilon_{0} \exp \left\{2 / 7 \cdot W_{\left.\mathrm{e}^{-0.35} \cdot F_{\mathrm{r}}\left(\xi^{7}-1\right)\right\}}\right. \\
& \ln \left(a_{0} / \varepsilon_{0}\right)=44.3\left(l_{0} / D_{0}\right)^{-0.75} \cdot R_{\mathrm{e}}^{-0.1}
\end{aligned}
$$

ここで, $W_{\mathrm{e}}$ は Weber 数, $F_{\mathrm{r}}$ は Froude 数, $R_{\mathrm{e}}$ は Reynold数である.これらの詳細は別報を参照されたい(37)38). なお液柱流に関する類似の研究が LANGEら 発表されているが，ガス巻さ込みについての本実験結果 は彼らのモデルを満足しなかつた。

\section{2 溶鋼注入流による酸素吸収}

いま溶鋼注入時の巻き込及気泡内の酸素は, すべて溶 鋼に吸収されると仮定すると，(3.1) 式から得られる $V_{\mathbf{g}}$ から, 注入全期間の累積巻き込みガス量 $G$ を求め, 注入 溶鋼量を $M$ とすると，平均吸収酸素量 $[\Delta \overline{\mathrm{O}}]_{\mathrm{E}} \%$ は

$$
\Delta[\overline{\mathrm{O}}]_{\mathrm{E}}=4.373 \times 10^{-3}(G / M)
$$

となる. あるいは, ノズル半径 $a_{0}$, ノズル出口線速度 $u_{0}$ を用いると，(3.11)式で求められる.

$$
\Delta[\overline{\mathrm{O}}]_{\mathrm{E}}=4.373 \times 10^{-3} V_{\mathrm{g}} /\left(\pi a_{0}^{2} u_{0} \rho\right)
$$

一方, 注入流の側面からの酸素吸収は, 注入流が極端 に乱れない限り，溶鉄自由表面を通しての酸素吸収と同 じで，(3.12)式および(3.13)式で表すことができる.

$$
\begin{aligned}
& \dot{n}=k_{\mathrm{g}}\left(p_{\mathrm{O}_{2}}-p_{\mathrm{O}_{2} \mathrm{i}}\right) / R T \cdots \ldots \ldots \ldots \\
& k_{\mathrm{g}} \cdot L / D_{\mathrm{N}_{2}-\mathrm{O}_{2}}=0.664 R_{\mathrm{e}}{ }^{1 / 2} S_{\mathrm{c}}{ }^{1 / 3}
\end{aligned}
$$

$L$ は代表長さ，ここでは注入高さ $Z(\mathrm{~cm}), \mathrm{N}_{2}-\mathrm{O}_{2}$ 混合 ガス中の酸素の拡散係数 $D_{\mathrm{N}_{2}-\mathrm{O}_{2}}$ をガス温度平均 $800^{\circ} \mathrm{C}$ として $2.5 \mathrm{~cm}^{2} / \mathrm{s}$ とし, シュミット数 $S_{\mathrm{c}}$ を 0.819 と すると(3.13)式は(3.14) 式のよらに簡単化される.

$$
k_{\mathrm{g}}=1.162\left(u_{0} / Z\right)^{1 / 2}
$$

また，注入流側面積は，液柱の乱れを無視すれば，液柱 半径 $a$ および流速 $u_{0}$ から計算され，したがつて側面か らの酸素吸収量 $\Delta[\mathrm{O}]_{\mathrm{st}} \%$ は(3.15)式で求めることがで きる。

$$
\begin{aligned}
\Delta[\mathrm{O}]_{\mathrm{st}} & =100 F_{1} \dot{n} M_{\mathrm{O}_{2}} /\left(\pi a_{0}^{2} u_{0} \rho\right) \\
& =1.722 \times 10^{-6}\left(u_{0} / Z\right)^{1 / 2} \\
& \left\{\left(2 g Z / u_{0}^{2}+1\right)^{3 / 4}-1\right\}\left(u_{0} / a_{0}\right)
\end{aligned}
$$

\section{3 溶銅注入時の酸素吸収田の推算}

一般の溶鋼注入時の酸素吸収量は，前節 (3.10)式およ び(3.15)式から計算することができるが，いま，任意の 条件下に打ける取鍋溶鋼量 $M$, 取鍋半径 $R_{1}$, 注入高さ $Z$ のときの酸素吸収量は, 次のように図から近似的に求 めることができる41). Fig. 10 (a) は, ノズル直径 $D_{0}=$ $5 \mathrm{~cm}$ のときの $M, R_{1}$ および $u_{0}$ の関係を, Fig. 10

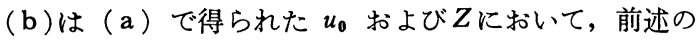
方法で計算した等 $\Delta[\mathrm{O}]_{\mathrm{E}}$ 線 (実線) および等 $[\mathrm{O}]_{\mathrm{st}}$ 線 （破線）をあらわす. いま一例として初期溶鋼量 $M_{\mathrm{i}}=$ 


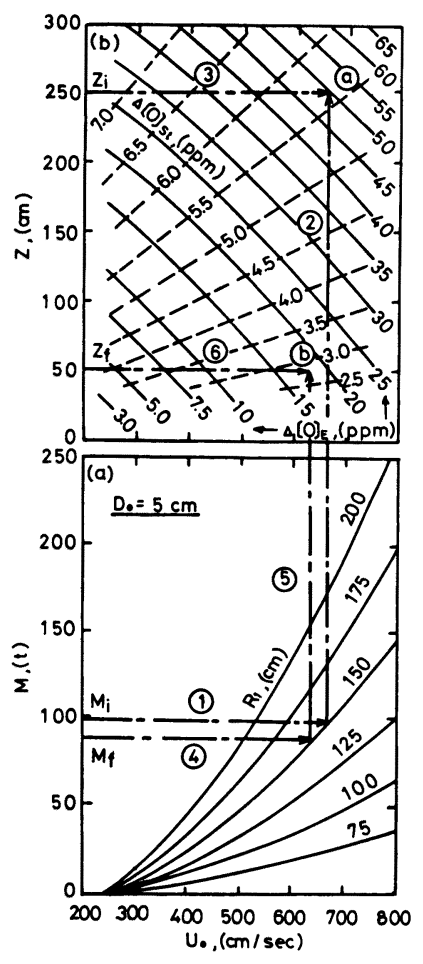

Fig. 10. A nomograph for estimation of oxygen amount absorbed by gas entrainment $\Delta[\mathrm{O}]_{\mathrm{E}}$ and through stream surface $\Delta[\mathrm{O}]_{\mathrm{st}}$. Снон, IwATA, INOUYE ${ }^{41)}$.

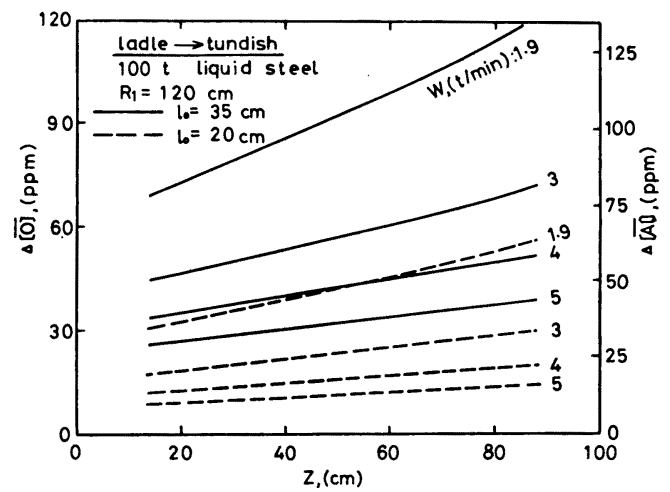

Fig. 11. Estimation of average oxygen absorption of liquid steel during teeming from ladle to tundish at several casting rates. Снон, Iwata, INOUYE ${ }^{41)}$.

$99 \mathrm{t}$, 末期溶鋼量 $M_{\mathrm{f}}=88 \mathrm{t}$, 取鍋半径 $150 \mathrm{~cm}$, 初期注 入高さ $Z_{\mathrm{i}}=250 \mathrm{~cm}$, 末期高さ $Z_{\mathrm{f}}=50 \mathrm{~cm}$ の場合は, 図 の@点および(b点における $\Delta[\mathrm{O}]_{\mathrm{E}}$ および $\Delta[\mathrm{O}]_{\mathrm{st}}$ の平 均值であり，それぞれ $34.1 \mathrm{ppm}$ および $4.2 \mathrm{ppm}$ とな る.
連続鋳造時の. 取鍋-タンディッシュ間の空気酸化は, アルゴンシールなどによつて防止されているが，いま空 気中で注入されるとして，この間の酸素吸収量を見積も つてみる. いま, 鋳造速度 $W \mathrm{t} / \mathrm{min}$ のもとで, $100 \mathrm{t}$ の 溶鋼が注入されたとすると, 同様の計算方法でガス巻き 込み速度 $V_{\mathrm{g}}$, 累積ガス巻き込み量 $G$ を求めて $\Delta[\mathrm{O}]_{\mathrm{E}}$ を 算出し, これに側面吸収量を加えた全酸素吸収量 $\Delta[\mathrm{O}]$ は, Fig. 11 に示すよらに, 当然のことながら, 注入長 さが大きいほど大きく，鋳造速度が大きいほど小さくな る. 図の右側縦軸には, 吸収酸素がすべて $\mathrm{Al}$ を酸化し たときの sol.Al の減少量を示した.これらの結果は, 巻き込まれた空気中の酸素が全部溶鋼に吸収されたとし

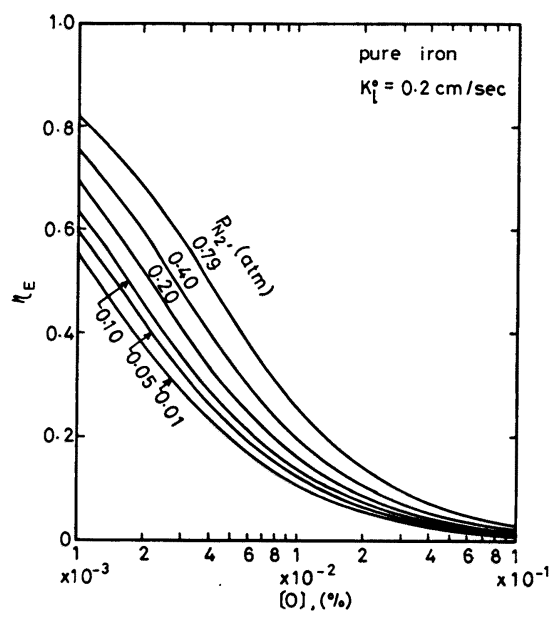

Fig. 12. Nitrogen absorption efficiency $\eta_{E}$ from gas entrainment defined by Eq. 3. 16 at $1600^{\circ} \mathrm{C}$. Inouye, Choh, Iwata ${ }^{49)}$.

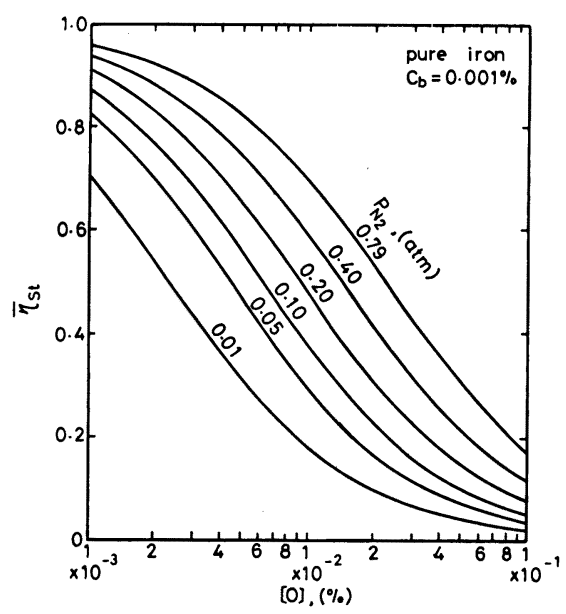

Fig. 13. Nitrogen absorption efficiency $\eta_{\text {st }}$ from stream surface at $1600^{\circ} \mathrm{C}$. InOuye, СноH, IWATA ${ }^{49)}$. 


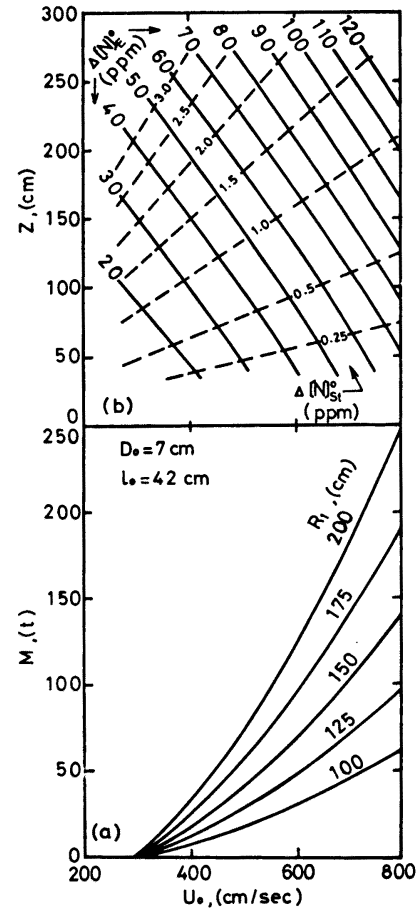

Fig. 14. A nomograph for estimation of nitrogen amount absorbed by gas entrainment $\eta_{\text {st }}$ and through stream surface at $1600^{\circ} \mathrm{C}$. INOUYE, CHOH, IWATA ${ }^{49)}$.

て求められたものであるが,ほぼ同じ条件下での実測值,

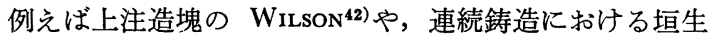
ら ${ }^{43)}$, あるいは栗田ら ${ }^{44)}$ の值とかなりよく一致している.

溶鋼注入流の酸素吸収については, SZEKELY45) む同様 の立場から解析を試みているが，ガス巻き込みの取り扱 いが著者らと異なる．また，極端に注入流が分解した状 態を想定した ScHWERDTFEGER ら46) の研究もあるが, このよらな条件下での酸素吸収は，ここでは取り上げな かつた。

\section{4 溶鋼の注入流による窒素吸収}

窒素については，さきに(1.14)式によつて吸収速度が あらわされることを述べた。すなわち, 窒素の吸収は, 溶鉄中の酸素の影響を大きくうけるので，一般に巻き込 み気泡中の窒素がすべて吸収されるとは限らない，そこ で溶鉄中の 酸素濃度が零の場合の総括物質移動係数を

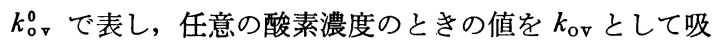
収効率 $\eta_{\mathrm{E}}$ を(3.16)式で定義した.

$$
\eta_{\mathrm{E}}=k_{\mathrm{ov}} / k_{\mathrm{ov}}^{0}
$$

巻き込及気泡からの吸収効率 $\eta_{\mathrm{E}}$ は石黒らによる転炉出 鋼時の窒素吸収の実測結果 ${ }^{47)}$ を利用し見積もることがで きる.ここで, 溶鋼中酸素零のとさ $100 \%$ 窒素が吸収さ れると仮定して前述のモデルから計算すると，このとき

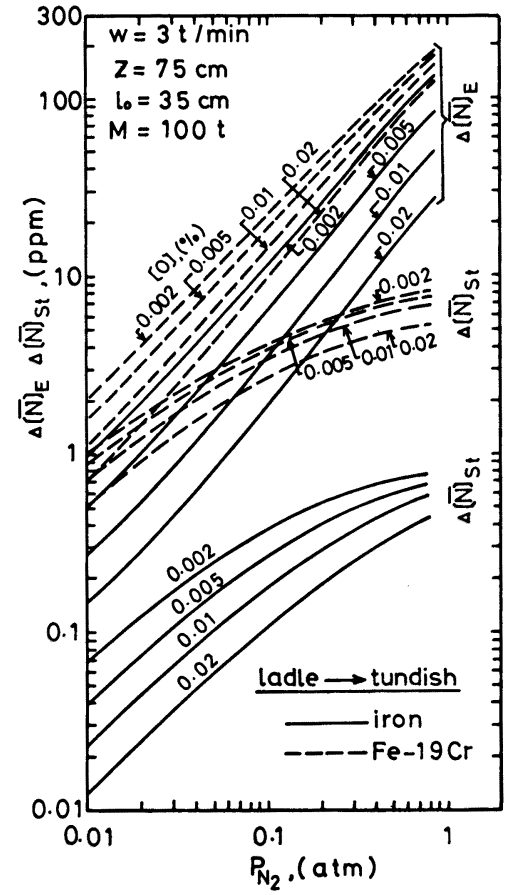

Fig. 15. Effect of Nitrogen partial pressure on nitrogen absorption in Liquid iron and $\mathrm{Fe}-19 \mathrm{Cr}$ melt during teeming from ladle to tundish. at $1600^{\circ} \mathrm{C}$. Inouye, Ghoh, Iwata ${ }^{49)}$.

の值 $\Delta[\mathrm{N}]_{\mathrm{E}}^{0}$ は約 $40 \mathrm{ppm}$ となり, 石黒らの低酸素レ ベルの実測值とほぼ一致するので48), これを酸素零のと きの吸収量とみなすまた，(1.14)式から種々の酸素濃 度に抽いて $k_{1}$ をパラメータとして $k_{\mathrm{ov}}$ を求め, $\eta_{\mathrm{E}}$ が きまると窒素吸収量 $\Delta[\mathrm{N}]_{\mathrm{E}}=\eta_{\mathrm{E}} \Delta[\mathrm{N}]_{\mathrm{E}}^{0}$ が得られる．以 下の計算には，実測值に最もよく合う $k_{1}$ の值を， 0.1 $\sim 0.2 \mathrm{~cm} / \mathrm{s}$ として用いた. 一方, 注入流側面からの窒 料吸収は(3.17)式から求められる.

$$
\Delta[\mathrm{N}]_{\mathrm{st}}=F_{1} \cdot k_{\mathrm{ov}} \cdot C_{\mathrm{e}} /\left(\pi a_{0}^{2} u_{0}\right) \cdots
$$

ただしこのときの $k_{\mathrm{ov}}$ は，高周波溶解の自由表面からの 室素吸収の物質移動係数（酸素零で $5.0 \times 10^{-2} \mathrm{~cm} / \mathrm{s}$ ) を とる.このよらにして側面からの吸収効率 $\eta_{\mathrm{st}}=k_{\mathrm{ov}} / k_{\mathrm{ov}}^{0}$ $=\Delta[\mathrm{N}]_{\mathrm{st}} / \Delta[\mathrm{N}]_{\mathrm{st}}^{0}$ を求めることができる.これらの吸 収効率， $\eta_{\mathrm{E}}$ および $\eta_{\mathrm{st}}$ は Fig. 12 および Fig. 13 に 示すように，もちろん酸素濃度が高くなるにつれ低下す るが， $\eta_{\mathrm{E}}$ の方がその影響が大きく，また減圧下では， $p_{\mathrm{N}_{2}}$ の低下とともに小さくなる.

\section{5 溶鋼注入時の窒素吸収田の推算}

前述の酸素吸収の場合と同じ手法で，任意の条件下に おける一定量の溶鋼注入時の窒素吸収量を求めることが できる ${ }^{49)}$. Fig. 14 はノズル直径 $7 \mathrm{~cm}$ の例であるが, このとき図から求められるものは, 大気中で溶鋼酸素濃 
度零のときの吸收量 $\Delta[\mathrm{N}]_{\mathrm{E}}^{0}$ および $\Delta[\mathrm{N}]_{\mathrm{st}}^{0}$ であり，一 般にはそのときの条件に応じて吸収効率 $\eta_{\mathrm{E}}$, あるいは 浓をかけなければならない。

また，連続鋳造の場合の一例をあげると，Fig. 15 の ようになる. アルゴンシールによつて $p_{\mathrm{N}_{2}}$ を0.01 atm 程度にすれば窒素吸収はほとんど無視できる。しかし， 空気中での注入時の実測值, 垣生ら ${ }^{42)}$ の $16.5 \mathrm{ppm}$ や窒 素シールしたときの成田ら50)の $20 \mathrm{ppm}$ といら值は本モ デルによる試算結果よりかなり小さく, 本モデルは窒素 吸収を高目に見積もつているものの，なおガス巻き込み 時の吸収速度の見積りに問題があろう.

\section{4.むす ひ}

溶鋼へのガス吸収の例として, 窒素および酸素の挙動 に関する最近までの研究結果をまとめて概説したが, 個 々の解析手法は別として, 大筋においては, 製鋼過程に おける窒素のコントロール，あるいは酸化防止を考える 上でもはや常識となつているといつてもよいかも知れな い. 事実現場においても，これらの結果をもとに有効な 手段がとられている例もみられる51). しかしながら，今 少し堀り下げてみると, 個々の反応機構や界面, あるい はその近傍の明確な理解はまだ得られていない.また新 しい観点からの研究を期待したい.

\section{文献}

1) L. $V$. Bogdandy, G. Schmolke and $I . N$. Stranski: Zeit. Elektrochem, 63 (1959), p. 758

2 ) $W . A$. Fischer and $A$. Hoffmann: Arch. Eisenhüttenwes., 31 (1960), p. 215; 33 (1962), p. 583

3 ) $H$. Schenck, $M . G$. Frohberg and $H$. HeinEMANN: Arch. Eisenhüttenwes., 33 (1962), p. 593

4 ) R. D. Pehlke and $J$. F. Elliott: Trans. Metall. Soc. AIME, 277 (1963), p. 844

5 ) $P$. Kozakevitch and $G$. Urbain: Mém. Scient., Rev. Mét, 60(1963), p. 143

6 ) 長 隆郎, 井上道雄：鉄と鋼, 53 (1967), p. 1393

7 ) 長 隆郎, 井上道雄：鉄と鋼, 54 (1968), p. 19

8 ) $M$. Inouye and $T$. Снон: Trans. ISIJ, 8 (1968), p. 134; 12 (1972), p. 189

9 ) 長 隆郎, 岡村正義, 井上道雄: 鉄と鋼, 55 (1969), p. 1176

10）例えば, 鉿木 鼎, 森一美, 伊藤洋平：鉄と鋼, 55 (1969), p. 877

11）佐野正道, 森 一美, 松島美継, 鈴木 鼎：鉄之 鋼，58 (1972)，p. 254

12) G. R. Belton: The Darken Conference

13) $R$. J. Fruehan and $L . J$. Martonik: Metall. Trans., 11B (1980), p. 615

14）成田貴一，小山伸二，牧野武久，岡村正義：鉄と 鋼, 57 (1971), p. 2207

15）萬谷志郎, 篠原忠広, 戸崎秀男, 不破 祐：鉄と
鋼, 60 (1974), p. 1443

16) $K$. Shinmyo and $T$. TAkami: Proceed. ICSTIS (1971) Part 1, p. 543

17) H. KNüPPEL and Oeters: Arch. Eisenhüttenwes., 33 (1962), p. 729

18）長 隆郎, 森谷 徹, 井上道雄：鉄と鋼, 64 (1978), p. 701

19) $T$. Снон, $T$. Moritani and $M$. Inouye: Trans. ISIJ, 19 (1979), p. 221

20）長 隆郎，山田哲夫，井上道雄：鉄と鋼，62 (1976), p. 334

21）長 隆郎, 竹部 隆, 井上道雄：鉄と鋼, 67 (1981), p. 2665

22）森 一美, 佐野正道, 門口維人, 村瀬文夫：鉄と 鋼, 67 (1981), S 860

23) P. Kozakevitch: Surface Phenomena of $\mathrm{Me}-$ tals (1968), p. 223 [Soc. of Chem. Ind.]

24) $P$. Kozakevitch and $G$. Urbain: Mém. Sci. Rev. Mét, 58 (1961), p. 401

25) $T$. Снон and $M$. Inouye: Arch. Eisenhüttenwes., 45 (1974), p. 657

26) D. G. G. Robertson and $A . E$. Jenkins: Heterogeneous Kinetics at Elevated Temperatures (1970), p. 393 [Plenum Press]

27) $T$. Emi, $W$. $A$. Boostein and $R$. D. Pehlke: Metall. Trans., 5 (1974), p. 1959

28) R. BAKER: JISI, 205 (1967), p. 637

29）大井 浩，森下 勝：川崎製鉄技報, 2 (1970), p. 14

30）伊藤公允，佐野幸吉：鉄と鋼，51（1965）， p. 1252

31）伊藤公允，佐野幸吉：鉄と鋼，49 (1963)， p. 1652 ; 同上, 50 (1964), p. 17

32) $S . K$. VIG and $W-K$. Lu: ISIJ, 209 (1971), p. 630

33) L. A. Greenberg and $A$. Mclean: Trans. ISIJ, 14 (1974), p. 395

34）長 隆郎, 井上道雄：鉄と鋼, 65 (1979), p. $52 ; 65$ (1979), p. 1720

35) $T$. Снон and $M$. Inouye: Trans. ISIJ, 20 (1980), p. 768

36) $T$. Gнoh, $Y$. Naganawa and $M$. Inouye: Trans. ISIJ, 20 (1980), p. 776

37）岩田勝吉，長 隆郎，井上道雄：鉄と鋼，68 (1982), p. 1922

38) $K$. Inata, T. Сhoh and $M$. Inouye: Trans. ISIJ, 23 (1983), p. 218

39) E. van de SANDE, $J$. $M$. Smith and $J . J . J$. van OORd: J. Appl. Phys., 45 (1974), p. 748

40) $P$. Massard and $K$. Lange: Arch. Eisenhüttenwes., 48 (1977), p. 521

41) 長 隆郎, 岩田勝吉, 井上道雄：鉄と鋼, 68 (1982), p. 2461

42) $W . W$ ILson: Metal Progress, 79 (1961) 5, p. 71

43）垣生泰弘, 北岡英就, 吉井 裕, 江見俊彦, 飯田 義治，上田典弘：鉄と鋼，62(1976), p. 1803

44) 栗田満信, 池田隆果, 丸川雄浄：鉄と鋼, 56 (1970), S 56

45) J. Szekely: Trans. Metall. Soc. AIME, 245 (1969), p. 341

46) $K$. Schwerdtfeger and $W$. Wepner: Metall. 
Trans., 8B (1977), p. 287

47）石黒守幸, 大久保益太：鉄と鋼，55 (1969), p. 492

48) 長 隆郎, 岩田勝吉, 井上道雄：鉄と鋼, 69 (1983)，p. 767

49) 井上道雄, 長 隆郎, 岩田勝吉: 学振 19 委-No.
10374 (昭和 56 年 10 月)

50) 成田貴一，富田昭津，広岡康雄，松本 洋，沢村 信幸, 進 貴志, 若杉 勇, 喜多幸雄: 鉄と鋼, 62 (1976), S 476

51）例えば，阿部泰久，西村光彦，片山裕之，高橋利 徳：鉄と鋼， 68 (1982), p. 1955 